\title{
JIHAD IN THE PERSPECTIVE OF AL-QURAN
}

\author{
Andi Anirah ${ }^{1}$ \\ Ibrahim Nasbih ${ }^{2}$ \\ Institut Agama Islam Negeri Palu ${ }^{1,2}$ \\ anirapalattae@ymail.com
}

\begin{abstract}
The main problem that will be discussed in this wrinting is what is the concept of jihad in the Quran. The problem is discussed using tafsir approach by Maudhu'iy method. The result of this research shows that: a) Jihad is way of struggle to do anything we can do to achieve a specific goal, whether by spoken or real actions. It also means to spread the Islamic teachings and values. Jihad, as it is mentioned in Quran, does not only mean a way to face against the enemy, hardship, or struggle for it, but also an act to eradicate stupidity, poverty and illness, self-control, wisdom and patience to confront all the miserableness; b) Jihad consisted of kinds of jihad, form of jihad, and way to do jihad. Jihad has two kinds. First, fighting the enemies (kafir and munafiq). Second, fighting against the carnality and fighting against the musyrikin opression. There are two forms of jihad, a jihad in the name of Allah and jihad for Allah. Jihad can be committed by Quran, weapon, wealthiness, and life; and c) Jihad is crucial that remind us again of who we are before God, and to estabilish a civilization under the preferences of Allah. Jihad is a pathway to the order. And to do so, struggle is a must. In Quran, jihad will be rewarded jannah (heaven), given a good grade from Allah, and will be fortunate.
\end{abstract}

Keywords: Jihad, al-Quran

\section{INTRODUCTION}

Quran will never textually change, but the interpretation does following to the space and time of the human being. Al-Quran must always be analyzed, perceived, and interpreted by tools, method, and approach in order to extract the core of its meaning. Many methods and interpretations are applied to look into the deep meaning of the Quran. ${ }^{1}$

Jihad is an endeavor to achieve goodness, a struggle to protect Islam by sacrificing our wealthiness, our body and soul. Jihad in the name of Allah is an obligation to all muslim based on their ableness.

There are many topics related to Jihad in Quran. If we see the sequence of verses in Quran about Jihad, we are essentially obliged to perform Jihad. In the first period of Islam, Jihad meant dakwah (spreading Islamic values) by estabilishing a dialogue between Muslim and Quraisy. ${ }^{2}$ This happened in the period of Makkah when God revealed a verse commanding Muslim to do dakwah using Quran to the Quraisy, as it is explained in al-Furqan:

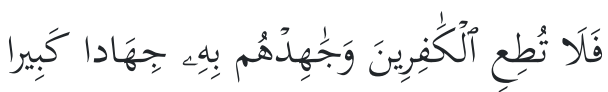

Meaning:

${ }^{1}$ Umar Shihab, Kontekstualitas Al-Quran: Kajian Tematik Atas Ayat-ayat Hukum dalam AlQuran, (Ed. 1; Jakarta: Penamadani, 2003), p. 3.

2 Ahmad, al-Tayyeb dkk. Jihad Melawan Teror: Meluruskan Kesalah pahaman tentang Khilafah, Takfir, Jihad, Hakimiyah, Jahiliyah dan Ekstrimitas (Jakarta: Lentera Hati.2016), p.154 
"So do not yield to the disbelievers, but strive diligiently against them with this Quran.",

An order to do Jihad proved that Muslim had been ordered to increase selfesteem by learning Quran in the early period of Islam. It can be used as a tool to deliver preach to the Quraisy who has no knowledge of Islam. Muslim was suggested to use Quran to the Quraisy through dialogue, so the message of Islam can be transmitted perfectly. ${ }^{4}$

Jihad mentioned in this verse does not refer to war. The term of Jihad is not limited to the intention of war. Instead, it has a broad meaning, particularly a religious practices. Jihad is an integral part of human being. It is a part of someone's personality. To be a perfect human being depends on how they perform Jihad, because it is one of the important teaching from Allah and given directly from Quran. Jihad has its own eminence to the religion and nation.

Based on the introduction above, the main topic that is about to be discussed in this research is that what is the concept of Jihad in Quran. To answer this question, the sub problem is divided into; a) what is the nature of Jihad in Quran? b) how is the Jihad in Quran? and, c) what is the urgency of Jihad in Quran?

\section{RESEARCH RESULT}

A. Jihad in Quran

The researcher divides Jihad in Quran:

1. Kinds of jihad in Quran

a. Jihad against the enemy

\begin{tabular}{|c|c|c|}
\hline No & Surah & Verses and meaning \\
\hline 1 & Al-Tahrim/66: 9 & 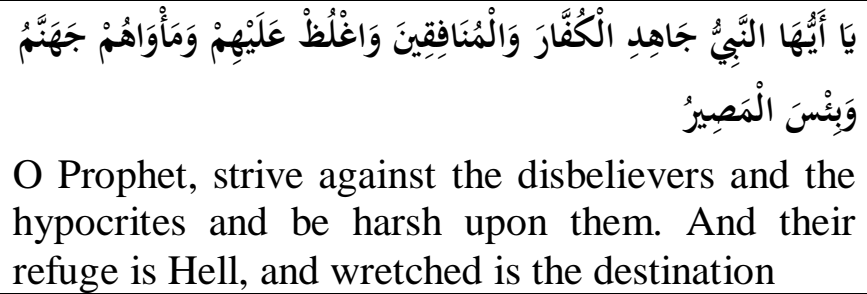 \\
\hline 2 & Al-Taubah/9: 73 & 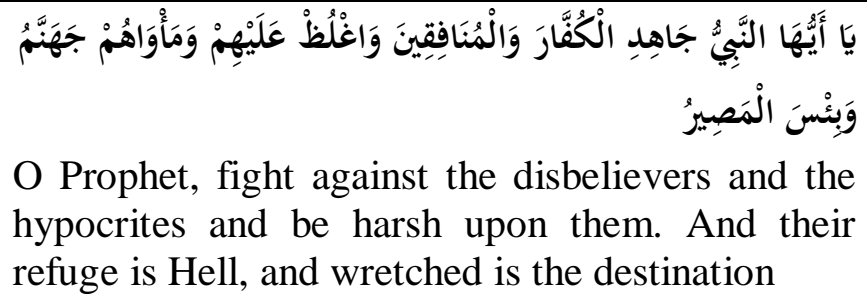 \\
\hline
\end{tabular}

Verses in the table above shows the command to do Jihad against kafir and munafiq. This kind of Jihad must be done harshly to any of these groups. Note that the existence of kafir at that time was a grave threat to the Muslim community.

${ }^{3}$ Al-Furqan/25:52

${ }^{4}$ Abdul Fattah - Memaknai Jihad Dalam Al-Quran dan Tinjauan Historis Penggunaan Istilah Jihad (J-PAI : Jurnal Pendidikan Agama Islam Vol. 3 No. 1 July-December 2016 ) p. 67 
According to Ibnu Mas'ud, Jihad against kafir must be done by "hand", otherwise by tongue, otherwise by heart. Ibnu Abbas, meanwhile, distincts between kafir and munafiq. To him, kafir must be fought by sword, while munafiq must be fought diplomatically by dialogue. ${ }^{5}$

b. Jihad against the carnality

\begin{tabular}{|c|c|c|}
\hline No & Surah & Verses and meaning \\
\hline 1 & Al-Ankabut/29: 6 & 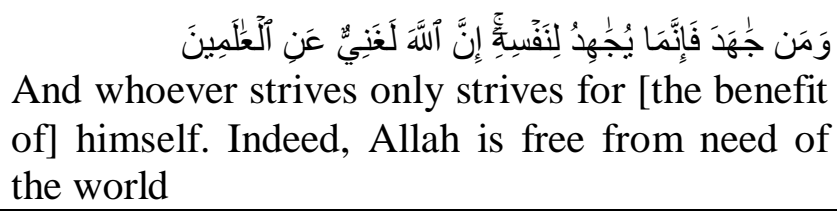 \\
\hline 2 & $\begin{array}{c}\text { Al-Ankabut/29: } \\
69\end{array}$ & 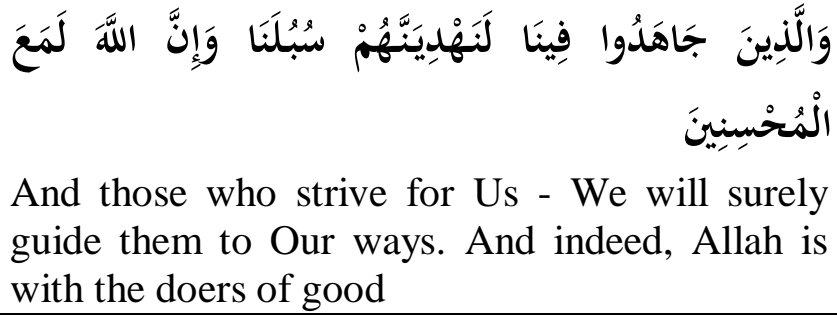 \\
\hline
\end{tabular}

Jihad against carnality mentioned in these verses (بَاهَدَ) means be resilience in obeying Allah and fighting the kafir. While the phrase جَاهِدُ لِنْفِسِه means that the jihad itself will return to te doers themselves. ${ }^{6}$

There are two interpretation derived from this verse. First, Jihad in terms of figthing the kafir and carnality, and being resilience in obeying Allah. Therefore, there will be a reward from it. Second, jihad to fight against the enemy for the benefit of one self, not for Allah. This kind of jihad will not be rewarded by Allah.

In other words, jihad can be perceived as hard work, struggle diligently, for the sake of the religion. Jihad can be done by hand, thought, wealthiness, and even our life.

Jihad to fight carnality is the hardest one, referring to one of the Prophet hadith:

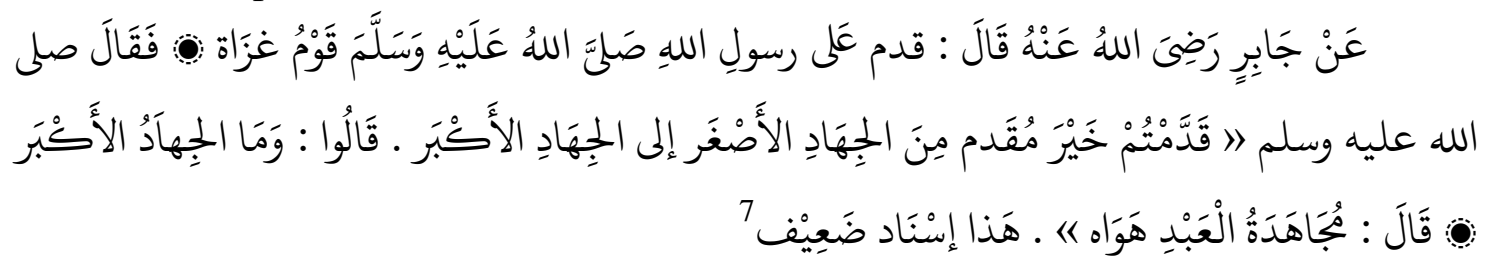

Meaning:

"You have returned from the lesser jihad, to the greater jihad." They inquired: "What is the greater jihad?" he said: "A person's jihad against his carnal desires.” (Narrated by: al-Baihaqi)

\footnotetext{
${ }^{5}$ See Ibnu Katsir, Tafsir al-Quran al-Adhim (Mesir: Darul Kutub al-Misriyah, t.th), p. 237

${ }^{6}$ Muhammad Ṭāhir bin 'Āsyūr, Tafsìr al-Tahrīr wa al-Tanwï, Juz. 19, p. 210.

${ }^{7}$ Al-Baihaqì, al-Zuhd al-Kabïr, Juz. 1, (Maktabah Syamilah), p. 388.
} 
c. Jihad against the opression of musyrikin

\begin{tabular}{|c|c|c|}
\hline No & Surah & Verses and meaning \\
\hline 1 & Al-Nahl /16: 110 & 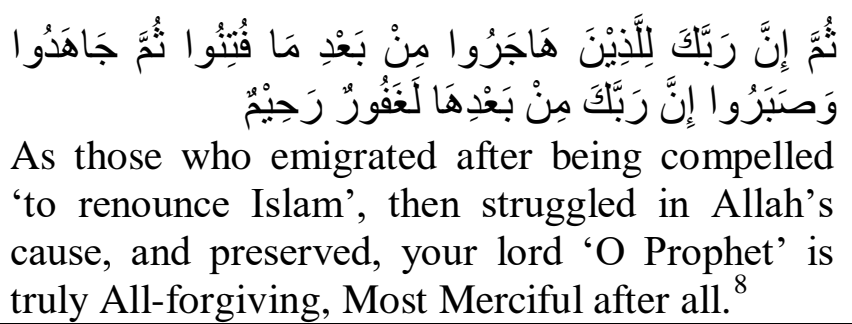 \\
\hline
\end{tabular}

To protect religion, Islam teach us to stay persistent in practising the commandments, one of them is jihad akbar. It is a barrier capable of deflecting all bad influences that could endanger the religion and our faith. To keep Islam prevailing, Islam allows us to get into war (Jihad asgar), but in condition that war is only for defensive measure, not vandalizing, and not killing the innocents. ${ }^{9}$

Three big things the Prophet and his companions did, they are emigrating (hijrah), jihad, and forbearing. Forbearing from trials from God is an act of jihad. Muslim are implicitly weak. We are economically, socially, militarily, and politically weak. When it came to such timing, the Prophet took a big step and emigrated to Habasyah.

\section{Forms of Jihad}

There are two forms of jihad in Quran. first, jihad fii sabilillah, or a jihad in the name of Allah, second, jihad fii al-Allah, or a jihad for Allah. The first one means an act of war against those who tries to eliminate Islam, and the second means an endeavor to serve blessing of Allah. According to Muhammad Husain al-Taba'tabaa'i, the term jihad followed by fii sabilillah is a jihad that refers to war, while the term jihad followed by fii al-Allah is a term tended to general jihad.

a. Jihad in the name of Allah

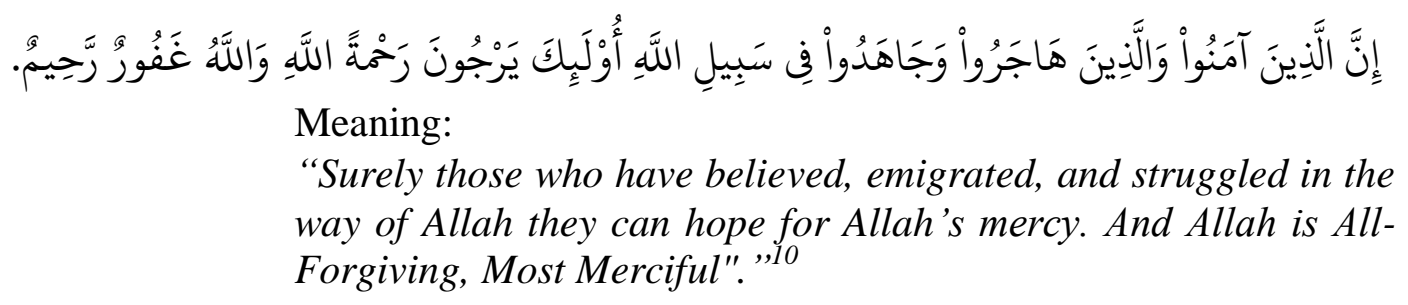

The verse above was meant to the Prophet and his companions when they emirated from Makkah to Madinah to escape from the opression of the musyrikin. He emigrated after the people of Madinah

\footnotetext{
${ }^{8}$ Ministry of Religious Affairs RI, al-Quran dan Terjemahnya, Ed. 2002, p. 380.

${ }^{9}$ Muhammad Khaer Haekal, al-Jihād wa al-Qitāl fi al-Syariah al-Islämiyah, Vol. I (Ed. II; Damascus: Dār al-Bayariq li al-Tiba'ah, 1996) h.46. see also Kasjim Salenda, Terorisme dan Jihad dalam Perspektif Hukum Islam (Ed. II; Makassar: Pustaka al-Zikra), p. 64-65

${ }^{10}$ al-Baqarah/2: 218
} 
declared to preserve the Prophet and the religion he delivered just as they preserve their own.

The Prophet arrived in Quba on Monday, 8 Rabiul Awwal, coincided on 23 September 622 AD. He then estabilished a mosque, the mosque that was built within the faith to Allah, as well as a mark between Makkah and Madinah era. ${ }^{11}$ The next verses related to the emigration is al-Anfal/8: 72-25.

Based on those verses, Muslim is divided into four groups:

1) Muhajirin, the first. They are people who emigrated along with the Prophet from the battle of Badar to the Hudaibiyah accord. They are called muhajirin because they left their homeland to preserve their religion, to escape from the opression, to pick a side of Muhammad, and to prevail Islam.

2) Anshar, the people of Madinah who provided shelter for the Prophet and Muhajirin.

3) Muslim who had yet to emigrate

4) Muslim who emigrated after the Hudaibiyah accord. ${ }^{12}$

The emigration resulted the union between Muhajirin and Anshar by the hand of the Holy Prophet. They were protecting and helping each other.

Aوجَاهَدُوا فِي سَبِيلِ اللَّه that is precious on them to gain the blessing of Allah. ${ }^{13}$

Jihad for the Muhajirin is to left their properties and families behind in the city of Makkah to emigrate to Madinah with intention to set Islam upright, whereas for the Anshar, jihad they did was to facilitate what the Muhajirin needed wholeheartedly. Such sacrafices is a proof that they conducted jihad in the name of Allah

b. Jihad for Allah

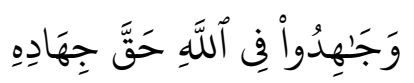

Meaning:

"Strive for the cause of Allah in the way He deserves...". 14

Jihad is also dutiful to parents, just as the hadith below mentioned:

${ }^{11}$ Ibrāhim al-'Ali, Sahīh al-Sïrah al-Nabawìyah, p. 115.

${ }^{12}$ Aḥmad Mustafa al-Marāâi, Tafsìr al-Marāgī, Vol. II (Ed. I; Egypt: Matba’ah Musțafā al-Babī al-Halabì, 1946), p. 137.

${ }^{13}$ M. Quraish Shihab, Tafsìr al-Mișbāh: Pesan, Kesan dan Keserasian al-Quran, Vol. I (Ed. II; Jakarta: Lentera Hati, 2004), p. 465

${ }_{14}$ Ministry of Religious Affairs RI, Mushaf al-Quran dan Terjemah ( Jakarta : Al-Huda Gema Insani, 2005 ), p. 342. 


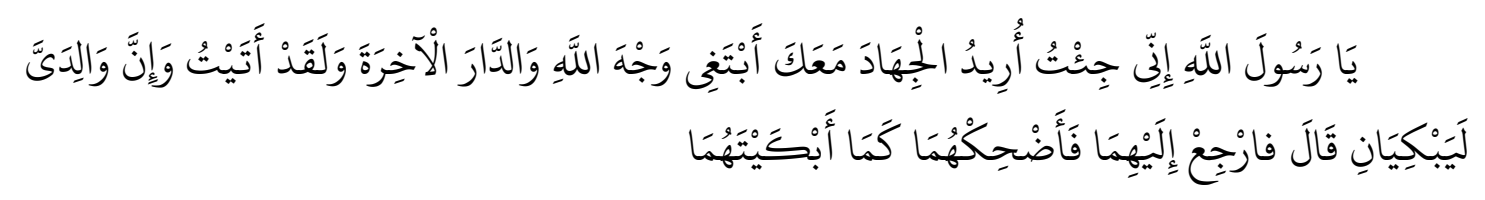

Meaning:

"A man came to the messenger of Allah and said: 'O Messenger of Allah, I have come seeking to go out in Jihad with you, seeking thereby the face of Allah and the Hereafter. I have come even though my parents are weeping.' He said: 'Go back to them and make them smile as you have made them weep." (Narrated by: Ibnu Majah)

Narrated by Umar bin Khattab and Uthman bin Affan, it is said that whoever go out and seek for war but his mother ask him to stay, hence he must stay with his mother. Therefore, Imam Syafi'i, Malik, Ahmad and 'Auzai agreed that going out to do jihad must bi with the permission of the parents. ${ }^{15}$

The substantial of that hadith is in line with the order of Allah to be dutiful to parents. It is explained in the al-Isra/17: 23 below:

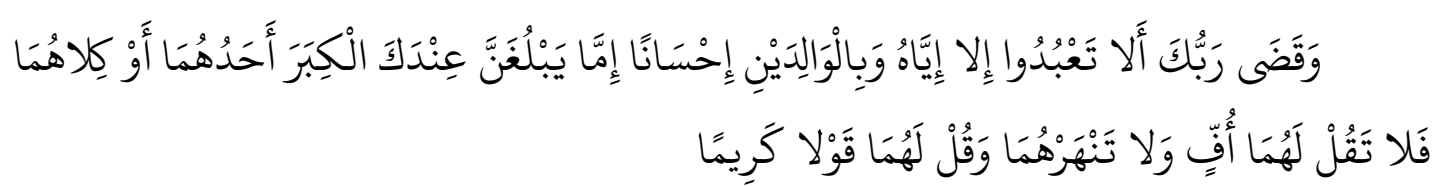

Menaing:

For your Lord has decreed that you worship none but Him. And honour your parents. If one or both of them reach old age in your care, never say to them even "ugh", nor yell at them. Rather, adress them respectfully

(حق جهاده) has a meaning of "the real jihad" in the name of Allah. To be persistent in reaching the blessing of Allah. And the sentence contains a higher spiritual meaning compared to jihad fii sabilillah.

3. Way to do jihad

a. Jihad with Quran

Quran as an instrument of jihad is mentioned in al-Furqan/25: 52

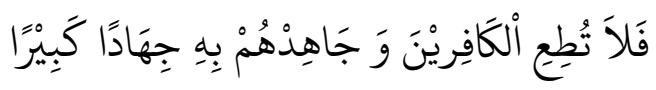

Meaning:

"So do not yield to the disbelievers, but strive diligently against them with this Quran.",16

The term جَاهِدَادَا This word has a meaning of al-masyaqqah (hardship). The word

\footnotetext{
${ }^{15}$ See, Syarh an-Nawawi, CD Room Maktabah Syamilah

16 Ministry of Religous Affairs RI, Mushaf al-Quran dan Terjemah ( Jakarta : Al-Huda Gema Insani, 2005 ), p. 365
} 
this verse refers to Quran, according to al-Tabari. ${ }^{17}$ The same tone is agreed by al-Taba'taba'i that that word points out to Quran. ${ }^{18}$

Based on that verse, jihad ordered since the period of Makkah has an important role in the Prophet spreading the Quran, particularly about Islamic values (aqidah). The effort of the Holy Prophet spreading a monotheist in the middle of the polytheistic environment was a one big struggle of jihad. Thus, Quran was the only weapon to use in order to deliver and introduce the Quran teaching

Therefore, the core of the phrase جهادا كبير is a willingness to spread the values of Quran with intentions to attract their attentions to Islam.

b. Jihad with wealthiness and life

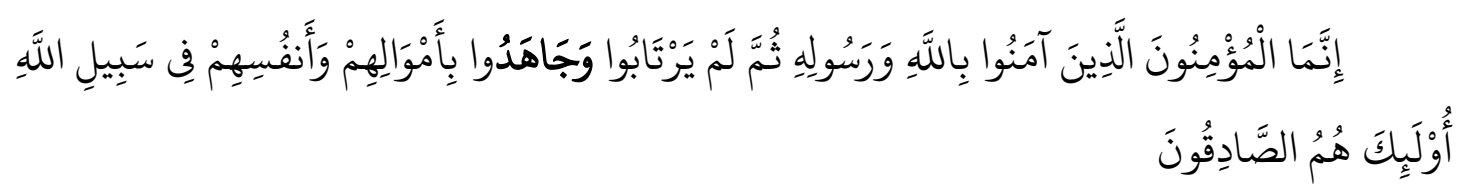

Meaning:

"The true believers are only those who believe in Allah and His Messenger, never doubting and strive with their wealth and their lives in the cause of Allah. They are the ones true in faith (alHujuraat/49: 15)"19

This verse was revealed when a bunch of men came to the Prophet and admitted their faithful, whilst Allah knew it was not true. Their admission was only a lip service and their true intention entering Islam was only to protect their own lives and wealthiness.

Other verses that mentioned the importance of jihad is in alTaubah/9: 19-20:

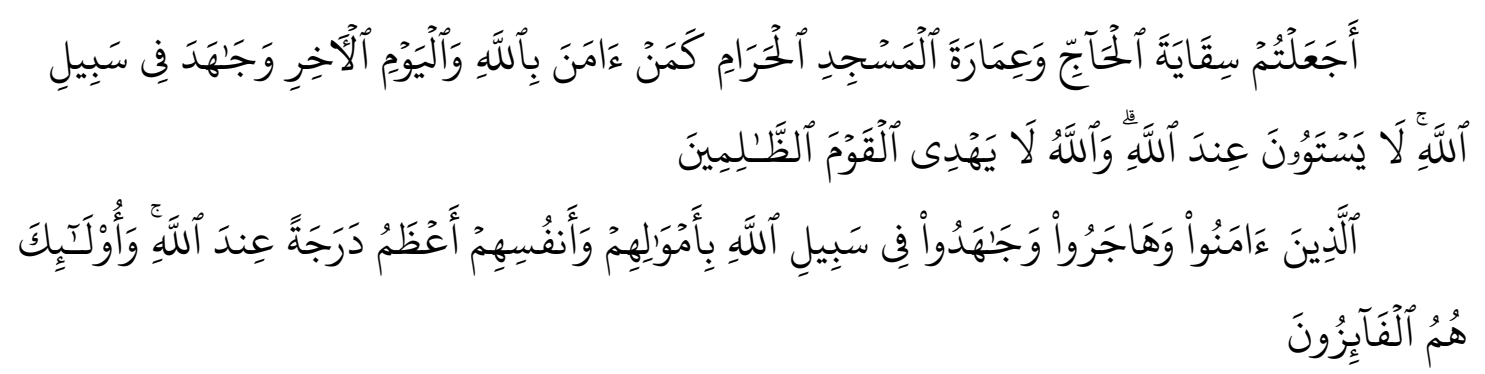

Meaning:

"Do you pagans consider providing the pilgrims with water and maintaining the Sacred Mosque as equal to believing in Allah and the Last day and struggling in the cause of Allah? They are not equal in Allah's sight. And Allah does not guide the wrongdoing people (19). Those who have believed emigrated,

\footnotetext{
${ }^{17}$ Abū Ja'far Muhammad ibn Jarìr al-Ṭabari, Tafsìir al-Tabarī Jāmi' al-Bayān 'an Ta'wīl alQur’ān, Juz 17 (Ed. I; Cairo: Markaz al-Buhūs wa al-Dirasāt Islāmiyah wa al-‘Arabiyah, 2001) p. 470

${ }^{18}$ Muhammad Husaìn al-Tabā'tabā'ì, al-Mizān fì Tafsir al-Qur'ān (Vol. XV (Beirut: Muassasah al-'Alamì li al-Mațū' at, 1983), p. 228

${ }^{19}$ Ministry of religious Affairs RI, Mushaf al-Quran dan Terjemah. p, 518.
} 
and strived in the cause of Allah with their wealth and their lives are greater in the rank in the sight of Allah. It is they who will triumph (20)., 20

The verses above is in line with the hadith of the Prophet, saying that jihad can be done by wealth, hands, or tongues:

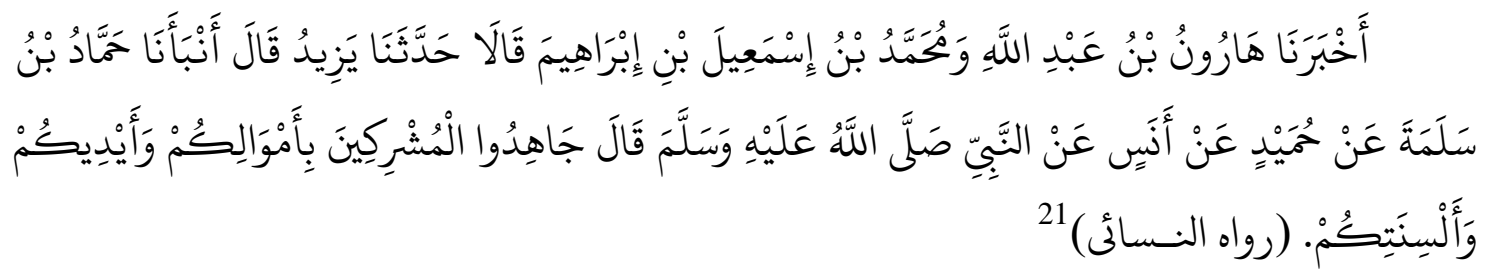

Meaning:

"Jihad against the idolators with your wealth, your hands, and your tongues."

Other hadith narrated by Imam Ahmad related to jihad with wealth in the form of hajj and umrah (pilgrimage):

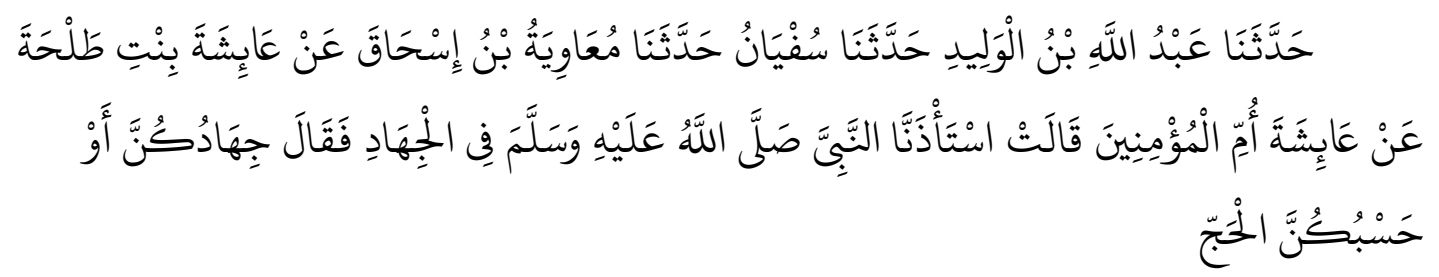

Based on the hadith above, jihad is divided into three; jihad with life, tongue, hands, and wealth. Jihad with tongue is sometimes more effective than the physical jihad. However, Jihad with heart is more suggested.

B. The urgency of jihad in Quran

Jihad is not only an evidence of our serivce to Allah, but also pathway to the triumph of Islam. Jihad is a spirit to change, and change cannot be earned without struggle, especially in the current condition of Muslim in all aspects, Jihad is the answer to bring out the revelation of thought, behavior, and actions of Muslims.

Jihad is the most noble among other prayers. It heaves up the name of Allah. Jihad comprises several worships, both physical and mental type of worship. Physical worships such as leaving hometown with intention of Jihad, and mental worship such as giving up life and wealth. Jihad is a form of love, power, and belief. $^{22}$

The advantages of Jihad according to Quran is:

1. Rewarded paradise, as explained in Ali Imran/3: 142

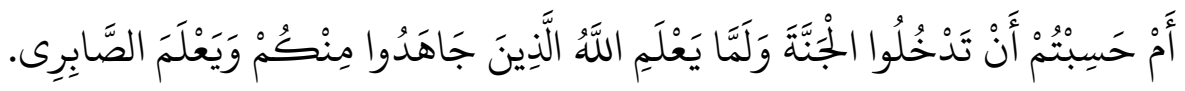

${ }^{20}$ Ministry of religious Affairs RI, Mushaf al-Quran dan Terjemah. P. 190

${ }^{21} \mathrm{Abu}$ 'Abd al-Rahman Ahmad al-Nasa'ì, Sunan al-Nasa'î, Juz V (Semarang: Toha Putra, 1930 M/1348 H), p. 6.

${ }^{22}$ Sayyid Sabiq, Fiqhi Sunnah 4. ( Jakarta ; Pena Pundi Aksara Ed, II. 2010 ), p. 442 
Meaning:

"Do you think you will enter Paradise without Allah proving which of you truly struggled for his cause and patiently endured?"

2. Rewarded an honour degree from Allah, as mentioned in al-Taubah/9:20

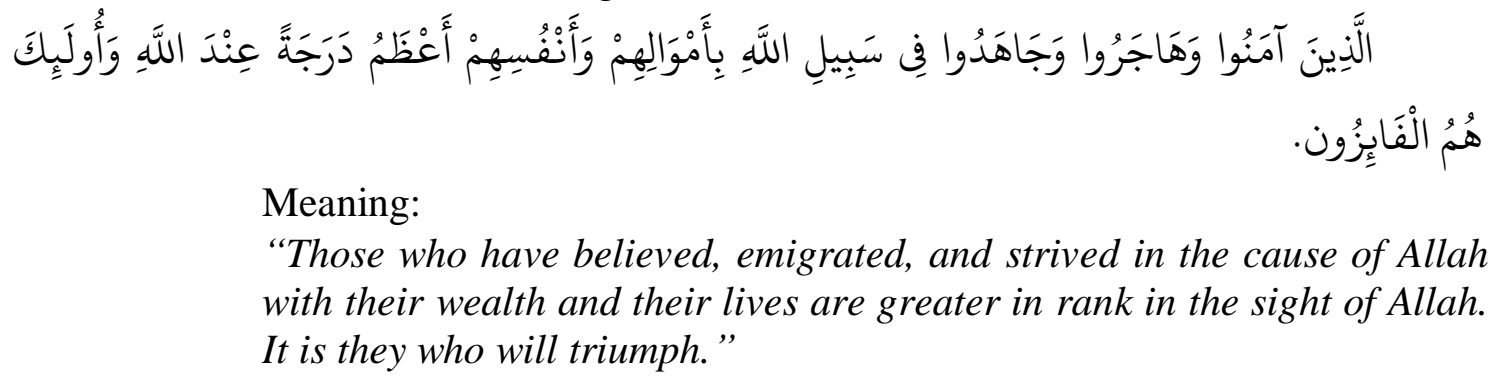

Meaning:

"Those who have believed, emigrated, and strived in the cause of Allah with their wealth and their lives are greater in rank in the sight of Allah. It is they who will triumph."

3. Getting goodness and fortunate, like in al-Taubah/9: 88

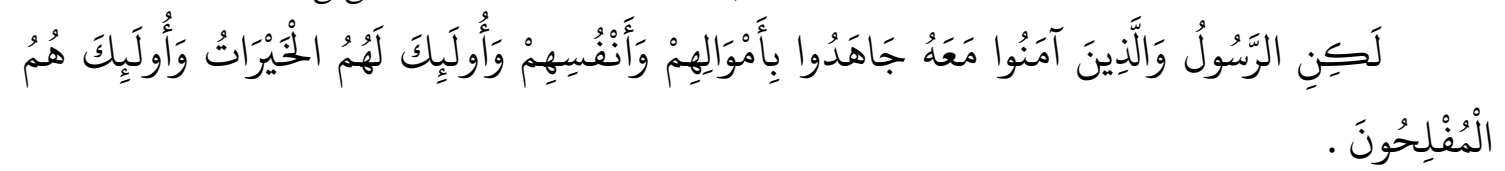

Meaning:

"But the Messenger and the believers with him strived with their wealth and their lives. They will have all the best, and it is they who will be successful."

Jihad is like trading, and the capital is faith to Allah and His Messenger, jihad with wealth and life, then there would be a benefit from Allah such as forgiveness and Paradise.

\section{CONCLUSION}

According to the explanations above, it can be concluded that: a) Jihad is a relentless effort to achieve a particular goal, to devote all of the words and actions for the sake of the religion. Jihad in Quran does not only mean a strive against the enemy, but also to eliminate stupidity, poverty, illness, self-control, wisdom, and endurance to all the trials; b) Jihad consisted of kinds of Jihad, forms of Jihad, and instruments of Jihad. Kinds of Jihad are fighting the enemies and carnal desires. Forms of Jihad are Jihad in the name of Allah and Jihad for Allah. While the instrument of Jihad is Quran, weapon, life, and wealth; and c) Jihad is not only as a reminder of the nature of us as a servant, but also as a pillars of the human civilization under the law of Allah. There will be change through Jihad. And the outcomes of Jihad is that there will be a reward from Allah such as paradise, good rank, and fortunate.

Throughout this writing, afterall, we would appreciate any suggestions or improvement, because we do understand that we are far from perfect. Therefore, further study about Jihad from different is really important. The topic of Jihad can be widen to education, social politics. For example, a scientist Jihad by their knowledge, etc. quoted from Jamal al-Bana in his book al-Jihad he said, Jihad today is more than just die for the sake of Allah, but to live and build social relationship and to do obligatories for the sake of Allah. 


\section{REFERENCE}

Al-Quran al-Karim.

Abd al-Baqi, Muhammad Fuad. Al-Mu'jam Mufahras Li Alfaz al-Quran al-Karim. Cairo: Dar al-Hadith, 2001

Abdul Fattah, Abdul. Memaknai Jihad Dalam Al-Quran dan Tinjauan Historis Penggunaan Istilah Jihad J-PAI: Jurnal Pendidikan Agama Islam Vol. 3 No. 1 July-December, 2016.

Al-Ali, Ibrāhim. Sahīh al-Sïrah al-Nabawìyah. Ed.I; Ammān: Dār al-Nafāis, 1995.

Al-Alūsī, Maḥmūd Syihāb al-Dīn Abū al-Ṡāā, Rūḥ al-Ma 'ānì fì Tafsìr al-Qur'ān al-

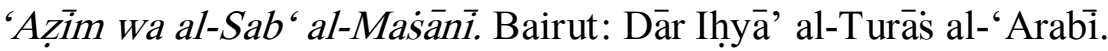

Al-Bannā, Jamāl. Al-Jihād. Cairo: Dār al-Fikr al-Islāmī, 2002.

Al-Bukhārī, Abū 'Abdillāh bin al-Mughīrah bin al-Bardizbah. Shahīh alBukhārī, juz II. Bairut: Dār al-Fikr, t.th.

Al-Hafisz, Ahsin A. W. Kamus Ilmu Al-Quran. Ed. I; Jakarta: Hamzah, 2005.

Al-Marāgi, Ahmad Mustafa. Tafsīr al-Marāgī, vol II, Ed. I; Egypt: Matba'ah Musțafā al-Babi al-Halabì, 1946

Al-Tayyeb, Ahmad dkk. Jihad Melawan Teror: Meluruskan Kesalah pahaman tentang Khilafah, Takfir, Jihad, Hakimiyah, Jahiliyah dan Ekstrimitas. Jakarta: Lentera Hati, 2016

Al-Tabā'tabā'̄i, Muhammad Husaīn. Al-Mizān fị Tafsìr al-Qur'ān, Jilid XV (Beirut: Muassasah al-'Alami li al-Matbuat, 1983.

Al-Tabarī, Abū Ja'far Muhammad ibn Jarìr Tafsìr al-Tabari Jāmi' al-Bayān 'an Ta'wìl Ay al-Qur'ān, Juz 17. Ed. I; Cairo: Markaz al-Buhūs wa al-Dirasāt Islāmiyah wa al-'Arabiyah, 2001.

Asfahānī, al-Rāgib. Mu'jam Mufradāt li Alfăz al-Qur'ān. Beirut: Dār al-Fikr, t.th.

Ash-Shiddieqy, TM. Hasbi. Mutiara Hadis, Jilid V. Semarang: PT. Pustaka Rizki Putra, 2003.

Haekal, Muhammad Khaer. Al-Jihād wa al-Qitāl fi al-Syariah al-Islāmiyah, Vol. I. Ed.; II; Damascus: Dar al-Bayariq li al-Tiba'ah, 1996.

Ibn 'Āsyūr, Muhammad Ṭāhir. Tafsìr al-Taḩrìr wa al-Tanwïr, Juz. 19. Tunis: al-Dār alTünisiyah li al-Nasyr, 1984.

Ibnu Fāris bin Zakariyya Abū al-Husain Aḥmad. Mu‘jam Maqāyīs al-Lugah, Juz. I. Beirut: Dār Ittihāa al-'Arabì, 2002.

Ibnu Kaṣir, Abū al-Fidā Ismā'î̀l. Tafsìr al-Qur'ān al-Karīm, juz I. Cairo: Dār alFikr, t.th.

Ibnu Mansur al-Ifriqi al-Misr, Abu al-Fadl Jamal al-Din Muhammad bin Mukram. Lisan al-Arab Juz XI (Beirut: Dar Al-Sadr, t.th. 
Kementerian Pendidikan dan Kebudayaan RI , Kamus Besar Bahasa Indonesia Edisi V, Badan Pengembangan dan Pembinaan Bahasa, 2016.

Munawwir, Ahmad Warson. Kamus Al Munawwir Arab-Indonesia, Surabaya: Pustaka Progresif, 2005

Muhammad, Imarah. Izālah al-Syubhàt 'am Ma'āni al-Muṣtalậăt, Cet. I; Kairo: Dār al-Salām, 2010.

Rohimin. Jihad: Makna dan Hikmah. Jakarta: Erlangga, 2006.

Shihab, M. Quraish. Tafsir al-Mishbah; Pesan, Kesan dan Keserasian al-Quran, vol. I (Ed. II; Jakarta: Lentera Hati, 2004.

Wawasan al-Quran: Tafsir Maudhu'i atas Pelbagai Persoalan Umat, Cet. XIV; Bandung: Mizan, 2003

Kontekstualitas Al-Quran: Kajian Tematik Atas Ayat-ayat Hukum dalam Al-Quran, Cet. 1; Jakarta: Penamadani, 2003.

Sabiq, Sayyid. Fiqhi Sunnah 4, Ed. II, Jakarta: Pena Pundi Aksara, 2010

Salenda, Kasjim. Terorisme dan Jihad dalam Perspektif Hukum Islam (Cet. II; Makassar: Pustaka al-Zikra, 2011.

Sami bin Abdullah bin Ahmad al-Maghluts, Atlas Sejarah Para Nabi dan Rasul, Mendalami Nilai-nilai Kehidupan yang dijalani Para Utusan Allah, (Jakarta: Obeikan Riyadh. Almahira, 2008.

Umar, Nasaruddin. Mengurai Makna Jihad dalam Kata Pengantar Gamal al-Banna, Jihad yang terjemahkan oleh Tim Mata Air Publishing. Cet. I; Jakarta: Mata Air Publishing, 2006. 